\title{
The coronavirus crisis and the technology sector
}

\author{
Carolyn Evans ${ }^{1}$
}

Published online: 23 November 2020

(c) National Association for Business Economics 2020

\begin{abstract}
The coronavirus crisis has created a profound shift in how people interact and economies function. Policy mandates and fears of becoming infected or infecting others have impelled populations to shelter at home, socially distance, and otherwise reduce direct, in-person interactions with others. By enabling people to conduct many regular activities remotely, including working, learning, shopping, and receiving medical services, technology has allowed the continuation of some semblance of a normal lifestyle in this new environment. Within this context, the IT sector has provided the tools and resources required to support these remote activities, as well as to address the pandemic more directly through efforts such as supporting contact tracing and providing high-performance computing resources for COVID-19-related research. This paper discusses in more detail this impact of the pandemic on the technology industry, and its response to this shock, by addressing three elements: accelerated digital transformation, increased importance of technology in the economy and society, and prevalence of inequalities in access to and the use of technology.
\end{abstract}

Keywords COVID-19 $\cdot$ Information technology $\cdot$ Digital transformation $\cdot$ Digital divide $\cdot$ Remote work $\cdot$ Remote learning

\section{Introduction}

The coronavirus crisis has created a profound shift in how people interact and economies function. Policy mandates and fears of becoming infected or infecting others have impelled populations to shelter at home, socially distance and otherwise reduce direct, in-person interactions with others.

By enabling people to conduct many regular activities remotely, including working, learning, shopping and receiving medical services, technology has allowed the continuation of some semblance of a normal lifestyle in this new environment. Within this context, the IT sector has provided the tools and resources required to support these remote activities, as well as to address the pandemic more directly through efforts such as supporting contact tracing and providing high-performance computing resources for COVID19-related research.

The views in this paper are solely the responsibility of the author and should not be interpreted as reflecting the views of Intel Corporation or of any other person associated with Intel Corporation.

\footnotetext{
Carolyn Evans

Intel Corporation, Santa Clara, CA, USA
}

This paper discusses in more detail this impact of the pandemic on the technology industry, and its response to this shock, by addressing three elements: accelerated digital transformation, increased importance of technology in the economy and society, and prevalence of inequalities in access to and the use of technology.

\section{Accelerated digital transformation}

From the rise of e-commerce to the increased use of video chat and connection via online platforms to the automation of some types of work, a global digital transformation has been underway for many years. With the onset of the pandemic in early 2020 , however, requirements to socially distance and shelter at home have served as catalysts to accelerate this process.

Technology leaders nodded to these changes when reporting quarterly results for the year. Satya Nadella of Microsoft noted, "We've seen 2 years' worth of digital transformation in 2 months" (https://www.microsoft.com/en-us/Investor/ earnings/FY-2020-Q3/press-release-webcast), and, "The last 5 months have made it clear that tech intensity is the key to business resilience. Organizations that build their own digital capability will recover faster and emerge from this 
Table 1 Changes to education for US households

\begin{tabular}{|c|c|c|c|c|}
\hline \multicolumn{5}{|c|}{ US Census Bureau Household Pulse Survey (Wave 1) } \\
\hline \multicolumn{5}{|c|}{ All results for households with children enrolled in private or public school } \\
\hline \multirow{2}{*}{$\begin{array}{l}\text { Proportions } \\
\text { responding }\end{array}$} & \multicolumn{3}{|c|}{ Household income groups } & \multirow[t]{2}{*}{ Tota } \\
\hline & $\begin{array}{l}\leq \$ 34,999 \text { House- } \\
\text { hold Income }\end{array}$ & $\begin{array}{l}\text { Household Income Between } \\
\$ 35,000 \text { and } \$ 149,000\end{array}$ & $\begin{array}{l}\geq \$ 150,000 \text { House- } \\
\text { hold Income }\end{array}$ & \\
\hline \multicolumn{5}{|c|}{ No change in education because schools did not close } \\
\hline Yes & 0.01 & 0.00 & 0.00 & 0.00 \\
\hline No & 1.00 & 1.00 & 1.00 & 1.00 \\
\hline \multicolumn{5}{|c|}{ Education moved online } \\
\hline Yes & 0.59 & 0.75 & 0.85 & 0.72 \\
\hline No & 0.41 & 0.25 & 0.15 & 0.28 \\
\hline \multicolumn{5}{|c|}{ Education moved to paper } \\
\hline Yes & 0.25 & 0.21 & 0.16 & 0.22 \\
\hline No & 0.75 & 0.79 & 0.84 & 0.78 \\
\hline \multicolumn{5}{|c|}{ Classes canceled } \\
\hline Yes & 0.53 & 0.42 & 0.35 & 0.44 \\
\hline No & 0.47 & 0.58 & 0.65 & 0.56 \\
\hline
\end{tabular}

The Household Pulse Survey data provide eight income groupings, which have been collected into the groups above. The $\$ 34,999$ and below group constitutes about $27 \%$ of the sample of families with children enrolled in public or private school, the $\$ 35,000$ to $\$ 149,999$ group about $58 \%$, and the $\$ 150,000$ and above group about $15 \%$ crisis stronger..."(https://www.microsoft.com/en-us/Inves tor/earnings/FY-2020-Q4/press-release-webcast). Sundar Pichai of Google stated (https://abc.xyz/investor/static/ pdf/2020Q2_alphabet_earnings_release.pdf?cache $=$ a881c 38), "We're working to help people, businesses and communities in these uncertain times." He also noted, "As people increasingly turn to online services, our platforms-from Cloud to Google Play to YouTube - are helping our partners provide important services and support their businesses."

Evidence of the acceleration of digital transformation falls into many areas. In this paper, I will mainly focus on learning, working and other activities that have abruptly shifted from in-person to home and other remote locations. After taking a deeper look into this acceleration, I will illustrate how the technology sector has responded.

\subsection{Learning from home}

With school closures around the world, remote learning has swiftly become the primary mode of education for many students. UNESCO (United Nations 2020) reported that on May 1, 2020, 174 nations had school (including primary, secondary and tertiary) closures, affecting 1.2 billion learners. Schools in another 17 countries were only partially open. Methods of continuing education for students have varied, but a UNESCO (2020) survey reported that more than half of educational systems globally used some form of online learning, such as an existing national online learning platform, new national online portals or other online platforms. In addition to online modalities, television and radio have also come into use in countries where the technology infrastructure would not support an online-only mode. ${ }^{1}$

Within the U.S., at the peak, at least 124,000 public and private schools and 55.1 million students were affected by coronavirus crisis-related K-12 school closures (Education Week 2020). The US Census Bureau's Household Pulse survey provides additional information on the shift to online learning. In Wave 1 data (https://www2.census.gov/progr ams-surveys/demo/technical-documentation/hhp/house hold-pulse-survey-questionnaire-week1-5.pdf), collected between April 23 and May 5, a vanishingly small proportion of households reported no change in how children received an education (Table 1 ). ${ }^{2}$ Overall, about $72 \%$ of households with children enrolled in a private or public school reported a shift to online education. About $22 \%$ reported a move to paper for remote learning. ${ }^{3}$

\footnotetext{
1 The World Bank provides a wealth of information on distance learning using various modalities, as well as examples of which different countries around the world have implemented remote learning. One example of the information is at https://www.worldbank.org/en/ topic/edutech/brief/edtech-covid-19.

2 The question referred to here is: "How has the coronavirus pandemic affected how the children in this household received education? Select all that apply." With selected choice, "There was no change because schools did not close."

3 The question referred to here is: "How has the coronavirus pandemic affected how the children in this household received education? Select all that apply." With selected choices, "Pandemic impact on education-Classes normally taught in person moved to a distance-
} 
Table 2 US work-from-home pre-coronavirus crisis, by industry Source: https://www.bls.gov/news.release/pdf/flex2.pdf, accessed September 2, 2020

\begin{tabular}{|c|c|c|c|c|c|c|c|c|}
\hline & \multicolumn{8}{|c|}{ Job flexibilities and work schedules_-2017 to 2018} \\
\hline & \multicolumn{8}{|c|}{ American Time Use Survey } \\
\hline & \multicolumn{2}{|c|}{ Total workforce } & \multicolumn{6}{|c|}{ Selected industries } \\
\hline & \multirow[t]{2}{*}{$\begin{array}{l}\text { Millions of } \\
\text { workers }\end{array}$} & \multirow[t]{2}{*}{ Percent } & \multicolumn{2}{|c|}{ Financial activities } & \multicolumn{2}{|c|}{$\begin{array}{l}\text { Education and health } \\
\text { services }\end{array}$} & \multicolumn{2}{|c|}{ Leisure and hospitality } \\
\hline & & & $\begin{array}{l}\text { Millions of } \\
\text { workers }\end{array}$ & Percent & $\begin{array}{l}\text { Millions of } \\
\text { workers }\end{array}$ & Percent & $\begin{array}{l}\text { Millions of } \\
\text { workers }\end{array}$ & Percent \\
\hline Could work from home & 42 & 29 & 6 & 57 & 10 & 26 & 1 & 9 \\
\hline Did work from home & 36 & 25 & 5 & 47 & 9 & 24 & 1 & 7 \\
\hline Total workers & 144 & & 10 & & 37 & & 13 & \\
\hline
\end{tabular}

Table 3 US work-from-home pre-coronavirus crisis, by income group Source: www.bls.gov/news.release/pdf/flex2.pdf, accessed September 2, 2020

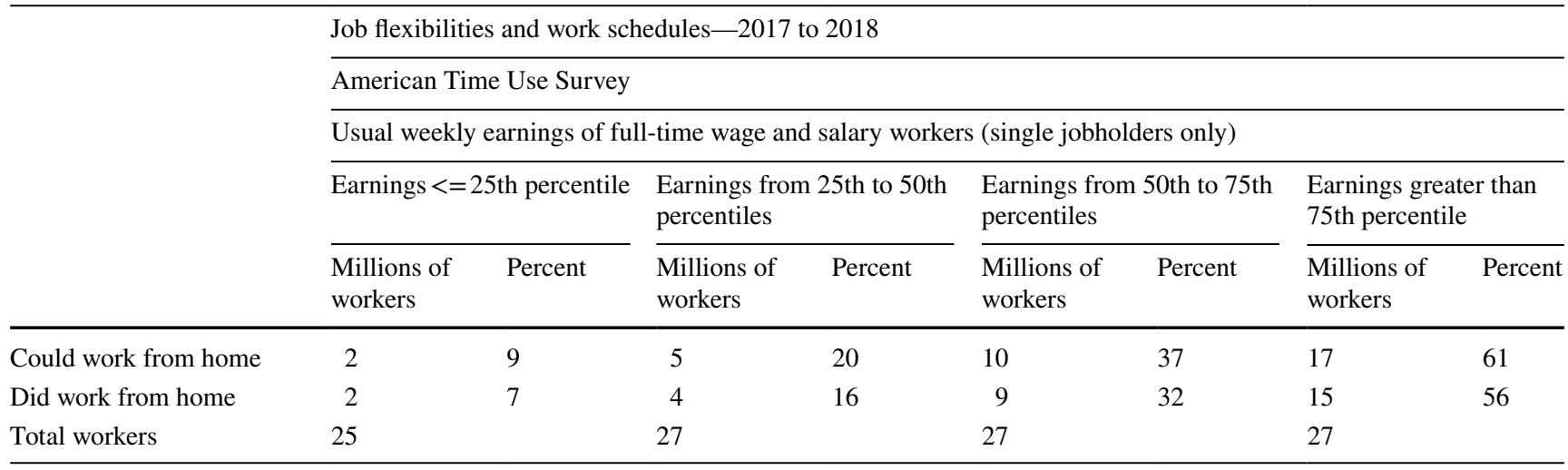

Thus, the pandemic has created an immense shift in learning models from in-person to remote learning, with technology as the tool critical to education for many students and teachers.

\subsection{Working from home}

In addition to the shift to learning from home, a parallel shift to working from home occurred.

To start, we must illuminate the fact that only certain types of jobs are feasibly done remotely. There are essentially two ways to measure working from home. One is through survey evidence of either individuals or of firms. The second is by understanding the content of work, and

\section{Footnote 3 (continued)}

learning format using online resources, either self-paced or in real time" and "Classes normally taught in person moved to a distancelearning format using paper materials sent home to children."
Table 4 UK work-from-home pre-coronavirus crisis Source: https:// www.ons.gov.uk/employmentandlabourmarket/peopleinwork/emplo ymentandemployeetypes/articles/coronavirusandhomeworkinginthe uklabourmarket/2019, accessed September 2, 2020

\begin{tabular}{llc}
\hline UK Annual Population Survey (APS) January to December 2019 \\
\hline & \multicolumn{2}{l}{ Total Workforce } \\
\cline { 2 - 3 } & $\begin{array}{l}\text { Milllions of } \\
\text { Workers }\end{array}$ & \\
\hline & 1.7 & 5 \\
Mainly work-own & 12 \\
Work at home in the week prior to interview & 4.0 & 27 \\
Ever work at home & 8.7 & 9 \\
Mainly work—same grounds or buildings or & 2.9 & \\
$\quad$ home as base & & \\
Total workers & 32.6 \\
\hline
\end{tabular}

whether or not the work could be done from home, together with an evaluation of employment patterns.

Tables 2, 3, and 4 show survey evidence on the percentage of people working from home prior to the pandemic. At 


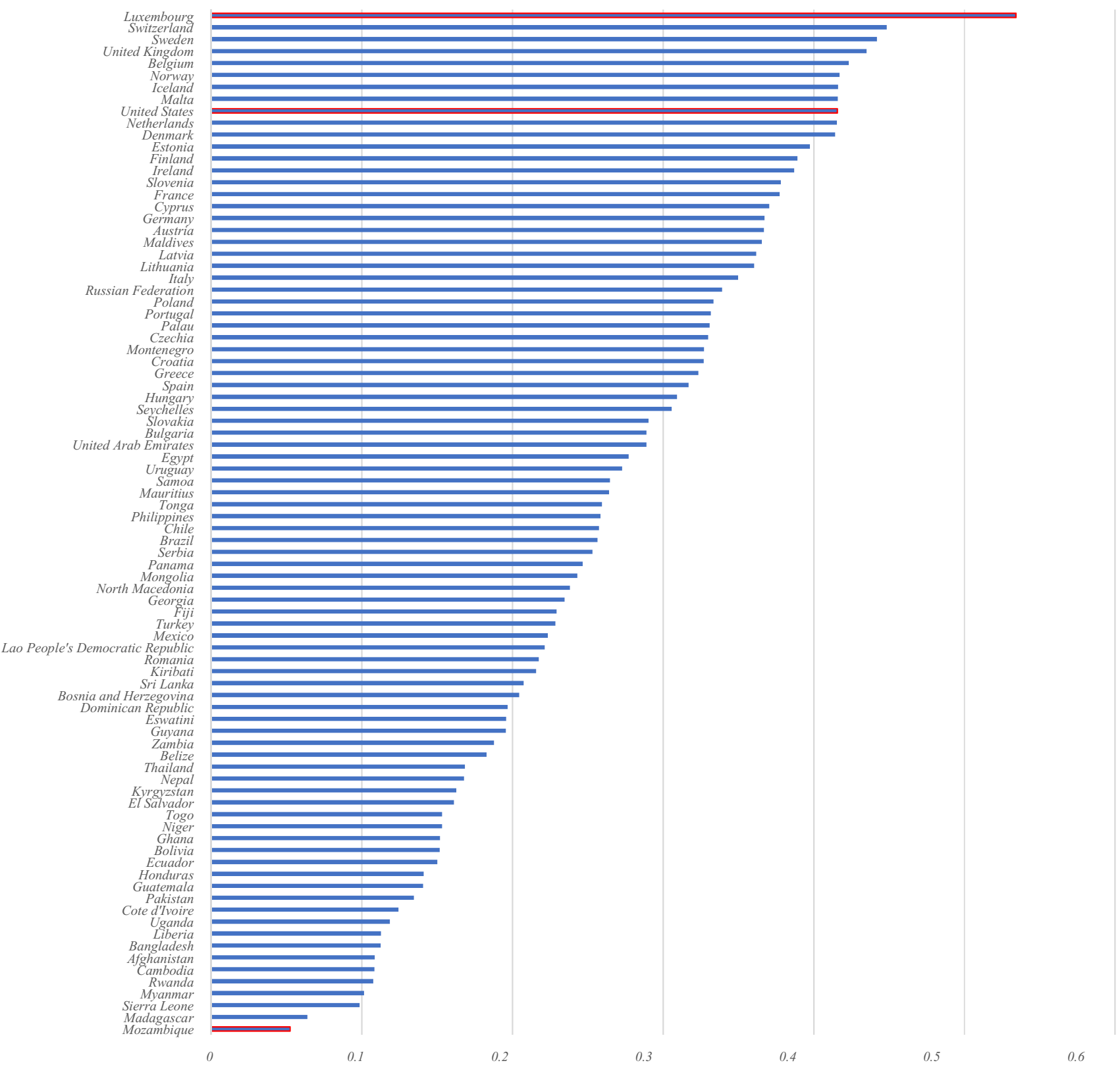

Fig. 1 Share of jobs that can be done at home Source: Dingel and Neiman 2020

that time, as shown in Table 2, about $29 \%$ of workers in the U.S could work from home, and about $25 \%$ did. Not surprisingly, there was variation across industries, with financial activities at the high end and leisure and hospitality at the low end. The incidence of the ability to work from home also varied across income groups (Table 3 ). In the lowest quartile, only $9 \%$ of workers could potentially work from home versus $61 \%$ in the highest quartile. In the UK (Table 4), the share of workers who ever work at home was $27 \%$.

In terms of the other way of measuring work from home-by type of work and employment by occupationFig. 1 shows the potential for employees to work from home across countries, using the estimates of Dingel and Neiman (2020; data available at https://github.com/jdingel/Dinge INeiman-workathome/blob/master/country_correlates/outpu t/country_workathome.csv). That share ranges from a low of $5 \%$ in Mozambique, to a high of 53\% in Luxembourg, with a positive correlation between per capita income and the share of jobs that can be done at home. The reported share for the USA was $42 \%$. Brussevich et al. (2020) also construct measures of "teleworkability" across countries, types of workers and occupations, finding a high degree of variation across all of these elements, with teleworkability increasing with GDP per capita and educational attainment. 
Table 5 Kaiser family foundation coronavirus March 2020 poll Source: Hamel et al. (2020)

\begin{tabular}{|c|c|c|c|c|}
\hline & \multirow[t]{2}{*}{ Total employed } & \multicolumn{3}{|c|}{ Household income } \\
\hline & & $<\$ 40 \mathrm{~K}$ & $\$ 40$ to $<\$ 90 \mathrm{~K}$ & $\$ 90 \mathrm{~K}+$ \\
\hline $\begin{array}{l}\text { Percent who say if required to remain at home because of a quarantine or school or work } \\
\text { closure, they could do at least part of their job from home }\end{array}$ & $45 \%$ & $29 \%$ & $42 \%$ & $63 \%$ \\
\hline
\end{tabular}

Fig. 2 Online shopping Source:

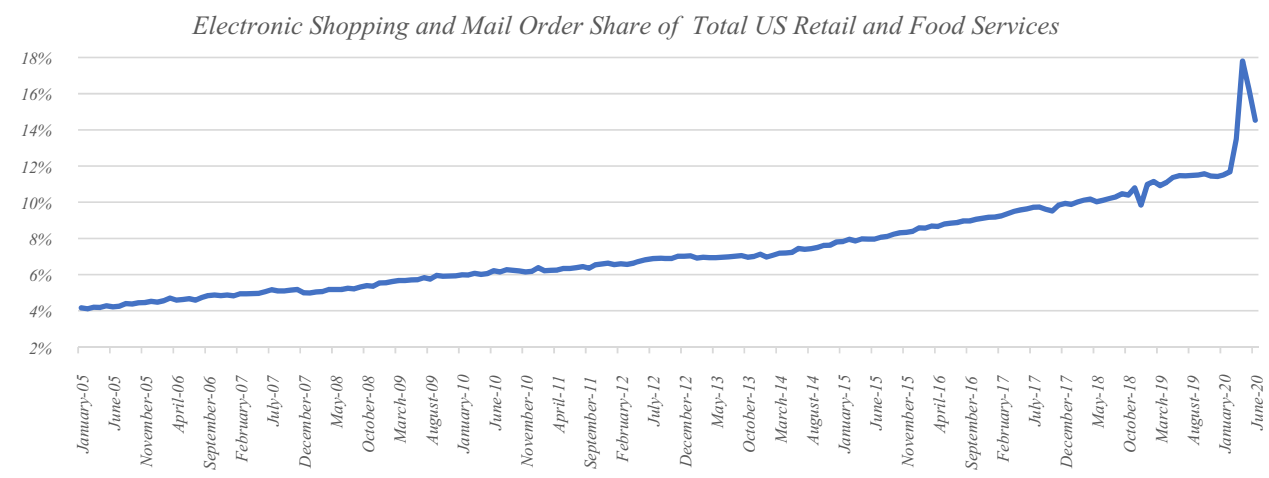
U.S. Census Bureau

Despite the fact that not all jobs can be done remotely, the coronavirus pandemic has greatly impacted work patterns in many economies. Surveys provide some evidence on the size of this impact in terms of the numbers of people who have shifted to working from home in the U.S. due to government mandates and shutdowns. Table 5 shows survey results from mid-March highlighting the effect of the pandemic on workers and employees. About $45 \%$ of respondents in the U.S. replied that they could do at least part of their job from home if needed to because of a school or work closure. Of course, there are limitations to comparability, but more respondents stated that they could work from home in this mid-March snapshot than in the survey results provided in Table 2. This $45 \%$ prevalence is also fairly close to the potential number of jobs that could be done remotely, provided by Dingel and Neiman (2020), and shown in Fig. 1.

Brynjolfsson et al. (2020) provide additional and more direct evidence of the magnitude of the movement to remote work. Surveys conducted in early April and early May found that about $35 \%$ of those working prior to COVID-19 switched to remote work, while another $15 \%$ had already been working remotely, implying that about half of the U.S. workforce was working remotely in the early stages of the crisis - a jump between pre- and mid-pandemic.

\subsection{Other activities from home}

A variety of other activities and services, including healthcare, shopping and entertainment, have moved from in person to remote or virtual.
For example, telehealth has grown during the pandemic. ${ }^{4}$ In 2018, the Peterson-KFF Health System Tracker found that $2.4 \%$ of adults enrolled in large employer health plans had used a telehealth service (Rae et al. 2020). In contrast, a survey conducted in April 2020 found that nearly 25\% of the U.S. population had experienced telehealth (https://morni ngconsult.com/wp-content/uploads/2020/05/2004100_cross tabs_CONTENT_CORONAVIRUS_Adults_v2_RG.pdf). According to FAIR Health, the share of medical claim lines for telehealth increased from $0.15 \%$ in May 2019 to $8.69 \%$ in May 2020 (https://s3.amazonaws.com/media2.fairhealth.org/ infographic/telehealth/may-2020-national-telehealth.pdf). Also in the U.S., Medicare primary care visits conducted via telehealth soared from $0.1 \%$ in February 2020 to $43.5 \%$ in April 2020 (Bosworth et al. 2020). In China, JD Health has seen a large increase in the use of telehealth during the coronavirus crisis (Augenstein 2020). Thus, as with learning and working from home, seeking and receiving medical attention from home grew during the pandemic.

The share of retail sales conducted via online shopping and mail order also grew strongly in March, rising to $13.5 \%$ from $11.7 \%$ the previous month (Fig. 2). In April, the share then shot up to $17.8 \%$. Although this share has since come back down, as of June it remained higher than in any month prior to April 2020.

\footnotetext{
${ }^{4}$ Also, an important note-in the United States, during the pandemic, a range of policy changes have made the provision of services via telemedicine easier and more reimbursable, in some cases, suggesting that policy will be an important aspect of the sustainability of these trends. See Weigel et al. (2020) for a discussion of this topic.
} 


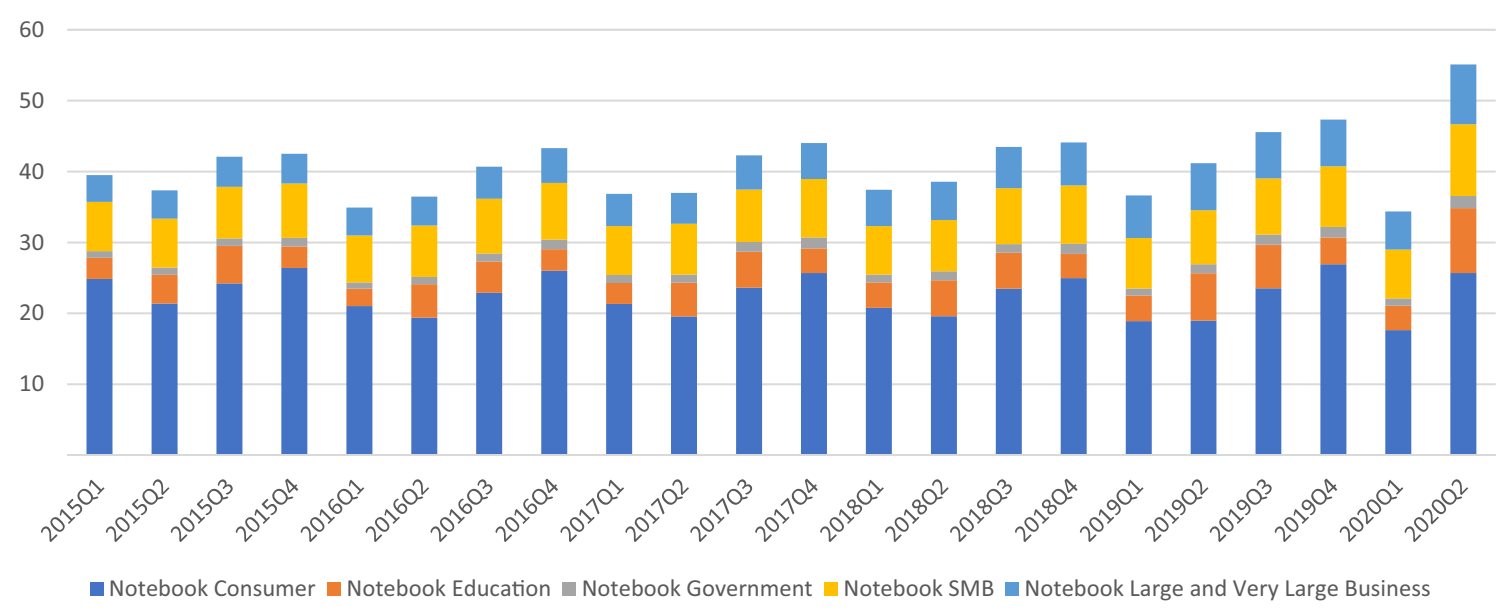

Fig. 3 IDC: worldwide notebook unit shipments (millions of units) Source: IDC Quarterly Personal Computing Device Tracker-PCD Final Historical 2020Q2

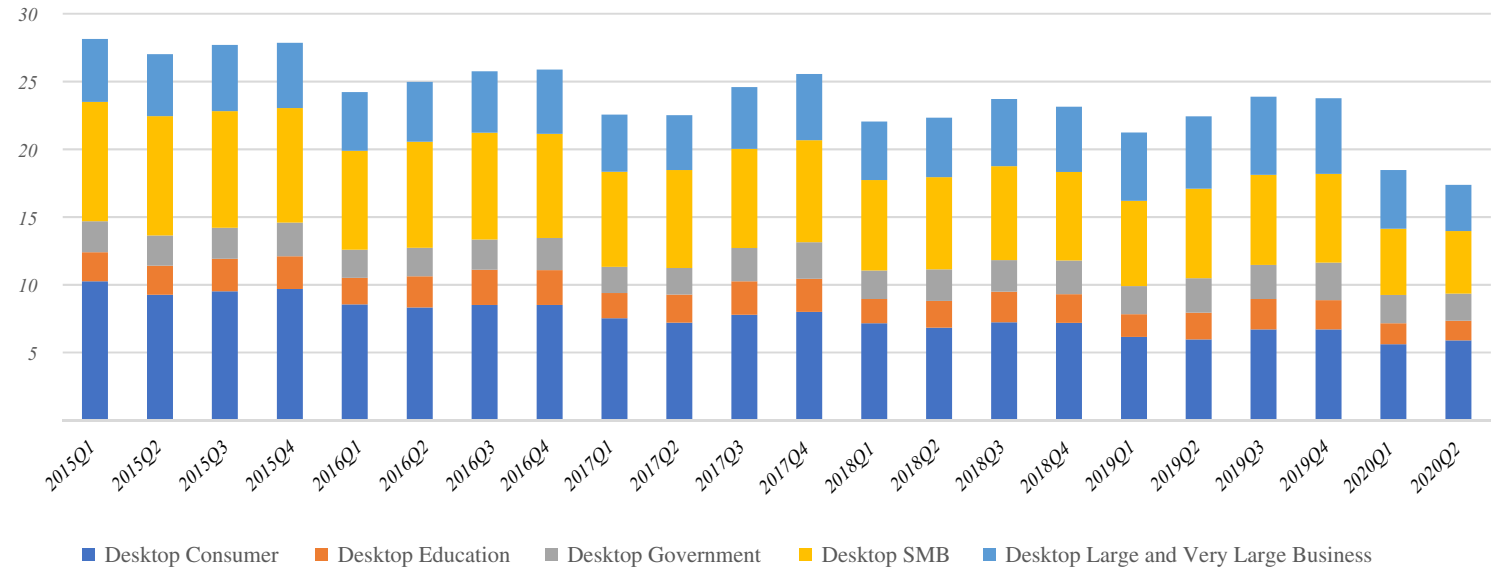

Fig. 4 IDC: worldwide desktop unit shipments (millions of units) Source: IDC Quarterly Personal Computing Device Tracker-PCD Final Historical 2020Q2

In the entertainment category, Netflix paid memberships across all regions increased $27 \%$ year over year (YoY) in the second quarter, compared to $22 \%$ YoY in 2019Q2. In the U.S. and Canada, 2020 Q2 paid memberships were up 10\% YoY, in comparison to 7\% for 2019 Q2 (https://s22.q4cdn .com/959853165/files/doc_financials/2020/q2/Q2'20-Websi te-Financials.xlsx).

\subsection{IT sector implications and response}

This acceleration in digital transformation has led to large increases in demand for technology products and services. The tech sector has responded by providing the tools needed for technology infrastructure, both through traditional channels and via charitable and other contributions.

For example, unit shipments of notebook computers soared in the second quarter of 2020 (Fig. 3). According to data from IDC, shipments of notebooks rose almost $34 \%$ from the previous year, whereas shipments of desktop computers fell (Fig. 4). This distinction between the two "form factors" is part of a broader movement observed in recent years of "notebook conversion." Examining the share of notebooks in total PC shipments over the last 5 years or so shows that there has been a slow shift (about $1 \%$ per year) toward notebook shipments. In the second quarter of this year, however, there was an abrupt change, in which the share of notebooks in total PC shipments was $76 \%$, whereas the average for 2019 was $65 \%$. To the extent that the workfrom-home and learn-from-home movements favor mobility, these shifts could be causal factors.

Although all segments grew strongly within notebooks, growth was especially robust in the education and consumer sectors. This strong growth was a shift particularly for the consumer sector. In 2019, consumer PC shipments fell from 


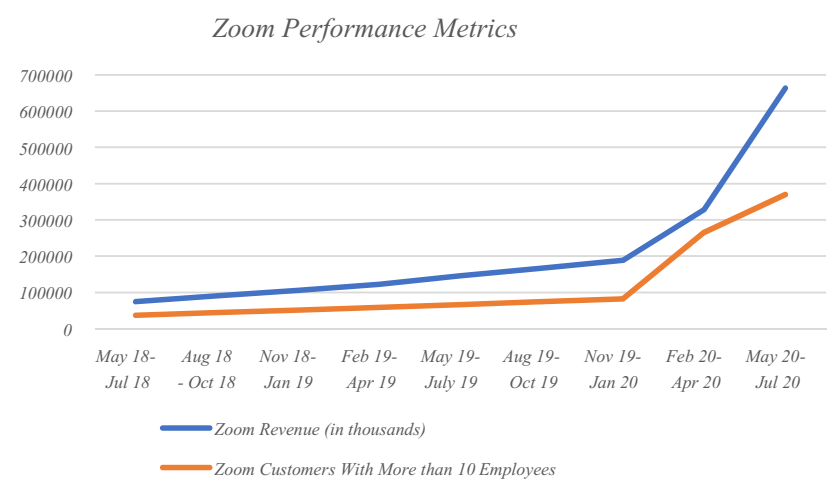

Fig. 5 Zoom performance metrics

the previous year, whereas in Q2, they grew 35\% YoY. The strength in consumer and education, in particular, is not surprising, as it happened with the huge shift to remote learning described above. Purchases for education often show up in the consumer numbers, so part of that strength is likely coming from the learning-from-home trend.

Thus, the massive shift to remote working and learning has led to a large increase in demand for computers. Shipment numbers for PCs bear this trend out.

In addition to higher demand for PCs, there has been a large increase in demand for cloud computing and digital services. Data on network traffic reflects this higher level of demand. On May 1, 2020, for example, AT\&T's core network traffic, which reflects business, home broadband and wireless usage, was up $22 \%$ compared to a similar day of the week pre-COVID (https://about.att.com/pages/COVID -19/network_archives.html). AT\&T's Wi-Fi calling minutes were up $73 \%$. These higher usage patterns had been evident since the end of March and were generally particularly true on certain weekdays, as opposed to weekends, suggesting that learning from home and working from home could be causal factors. As another data point, OpenVault reported average broadband usage during business hours very roughly 20\% higher post COVID-19 (https://openvault.com/trusted/2.

Plume also provides information on online activity from homes. Based on data from Wi-Fi services within homes, they observed that people were much more active online during the workday after the start of the pandemic than they were before. The number of people active online increased by almost $100 \%$ between the end of January and late March (Engebretson 2020). As of August 28, 2020, it was still up in comparison to pre-COVID, but by a somewhat lower $75 \%$ (https://discover.plume.com/wfh-dashboard).

As for digital services, as one example, the Zoom platform for remote meetings uses the number of customers with more than 10 employees as a performance metric. Growth has been strong generally in recent years, but between
May and July, the number of customers with more than 10 employees was up 458\% YoY, hitting 370,200 (Fig. 5). ${ }^{5}$

In addition to ensuring infrastructure availability for purchase, the technology sector has supported this massive digital transformation via charitable contributions. For example, Microsoft has made Microsoft Teams, which facilitates remote work and learning, free for a variety of groups, including schools and nonprofits. ${ }^{6}$ Microsoft has also partnered with UNICEF to accelerate expansion of a digital learning platform ${ }^{7}$ and increased support for nonprofits. ${ }^{8}$ Intel, Amazon Web Services (AWS) and Career Launcher partnered to create an online learning platform, Project Aspiration 2020, to support online learning in India (https://www.intel.com/content/www/us/en/corporate-respo nsibility/covid-19-aws-career-launcher-article.html). CDWG, Intel, Lego Education and First Book launched the Creating Learning Connections Initiative, intended to support remote learning for underserved students and educators in the U.S. ${ }^{9}$ Amazon has assisted small businesses by providing some free access to business tools and cloud computing services (https://s2.q4cdn.com/299287126/files/doc_financials /2020/Q1/AMZN-Q1-2020-Earnings-Release.pdf).

\subsection{Summary}

The COVID-19 pandemic propelled the shift toward virtual activities throughout the economy, and the technology

\footnotetext{
5 Information gathered from Zoom financial reporting forms: $10 \mathrm{Q}$ for period ending April 30, 2020: https://sec.report/Document/00015 85521-20-000154/\#i752ad573fa5e45489840543f7ec56fbb_79; $10 \mathrm{~K}$ for fiscal year ending January 31, 2020: https://sec.report/Docum ent/0001585521-20-000095/\#id55bd482f0f1415a87533af0809c6 e25_1144; $8 \mathrm{~K}$ for period ending July 31, 2020: https://sec.report/ Document/0001585521-20-000231/; $8 \mathrm{~K}$ for period ending October 31, 2019: https://investors.zoom.us/static-files/d260c2e2-6ca1-42c5a90d-0180d7e0a95f; 10Q for period ending April 30,2019: https:// investors.zoom.us/static-files/1eef0edd-78b6-449e-89dc-2d6b068c9b 89; 10Q for period ending July 31, 2019: https://investors.zoom.us/ static-files/cbb54248-55ea-4b58-acb9-690a95b87387; 10Q for period ending October 31, 2019: https://investors.zoom.us/static-files/51bf4 756-ebac-44a5-964e-4a7c30dc63d2. All accessed September 2, 2020.

${ }^{6}$ https://www.microsoft.com/en-us/microsoft-365/microsoft-teams /free?\&OCID=AID2000955_SEM_Xe7cUAAAAHnJziPd:20200 228221128:s\&msclkid=54b052bc6b1f119cd58f0ce5fb12755d\&ef_ id=Xe7cUAAAAHnJziPd:20200228221128:s\#coreui-contentrichbloc k-yxuv2bc, accessed September 3, 2020.

7 https://news.microsoft.com/2020/04/19/unicef-and-microsoft-launc h-global-learning-platform-to-help-address-covid-19-education-crisi s/, accessed September 3, 2020.

8 https://blogs.microsoft.com/on-the-issues/2020/04/13/tech-for-socia 1-impact-covid-19-azure/, accessed September 3, 2020.

${ }^{9}$ https://newsroom.intel.com/news/intel-initiative-help-studentsschool-districts-overcome-covid-19/\#gs.cwt462, accessed September 3, 2020.; https://firstbook.org/wp-content/uploads/2020/08/CreatingLearning-Connections-Initiative_Press-Release_FINAL-8.11-8.7.20002.pdf, accessed September 3, 2020.
} 
Table 6 Share in US household personal consumption expenditures of select products Source: U.S. Bureau of Economic Analysis

\begin{tabular}{|c|c|c|c|c|}
\hline & Jan-20 (\%) & Apr-20 (\%) & Jul-20 (\%) & $\begin{array}{l}\text { Change in share Jan } \\
\text { '20 to Jul '20 (\%) }\end{array}$ \\
\hline Personal computers/tablets and peripheral equipment & 0.40 & 0.51 & 0.51 & 28.38 \\
\hline Computer software and accessories & 0.72 & 0.87 & 0.88 & 23.40 \\
\hline Video streaming and rental & 0.17 & 0.22 & 0.19 & 14.21 \\
\hline Personal care products & 1.00 & 1.15 & 1.08 & 8.73 \\
\hline Telephone and related communication equipment & 0.21 & 0.17 & 0.23 & 7.01 \\
\hline Cellular telephone services & 0.93 & 1.14 & 0.97 & 4.10 \\
\hline Internet access & 0.53 & 0.67 & 0.55 & 4.07 \\
\hline Clothing and footwear & 2.81 & 1.84 & 2.73 & -2.89 \\
\hline Outpatient services & 8.00 & 6.26 & 7.67 & -4.12 \\
\hline Purchased meals and beverages & 5.83 & 3.87 & 5.19 & -11.00 \\
\hline Motor vehicle rental & 0.15 & 0.08 & 0.09 & -40.69 \\
\hline Public transportation & 1.28 & 0.15 & 0.63 & -50.40 \\
\hline Hotels and motels & 0.83 & 0.18 & 0.39 & -52.69 \\
\hline Personal care services & 1.15 & 0.17 & 0.34 & -70.09 \\
\hline Motion picture theaters & 0.09 & 0.00 & 0.00 & -97.80 \\
\hline Spectator sports & 0.21 & 0.00 & 0.00 & -99.90 \\
\hline
\end{tabular}

Calculations exclude expenditures of nonprofit institutions serving households (NPISHs) from total household personal consumption expenditures

sector has been stepping up to meet the higher demand for the required goods and services. As such, the pandemic served to accelerate a digital transformation that was already underway.

\section{Increased importance of technology in economy and society}

Commensurate with the massive increase in demand for technology products and services, the technology sector has taken on an increasingly important role throughout the economy and society.

\subsection{Consumer spending}

As a first cut, data on the distribution of consumption expenditures provide telling evidence (Table 6). U.S. data on household personal consumption expenditures show that the share of household consumer expenditures going to PCs/ tablets and peripheral equipment, and computer software and accessories increased rapidly, by $28 \%$ and $23 \%$, respectively, between January 2020 and July 2020. At the same time, the share of expenditure going to a range of categories, such as spectator sports, movie theaters and personal care services, plummeted, as services around the country shut down, perhaps making funds available for purchases more suited to the work-from-home and learn-from-home transformations described above. In fact, the share of expenditures going to
PCs/tablets and peripheral equipment soared to the highest in the data history, exceeding even the levels reached during the tech bubble of the late 1990s (Fig. 6).

These consumption data also provide indirect evidence of a shift in modalities. For example, while expenditures and the share of spending going to motion picture theaters plummeted, expenditures on video streaming and rental services rose by $27 \%$ between January and July, with the share of expenditures rising by $14 \%$.

\subsection{Corporate performance and valuation}

Data on the corporate sector also illustrate the increasing importance of technology, both as a way of operating very broadly and as an overall sector.

A shift in modality is evident within individual firms, where the ability to conduct business online contributed strongly to quarterly performance. As one example, Target Corporation's 2020 Q1 comparable sales grew 10.8\% YoY, with digital comparable sales expanding by $141 \%$, contributing 9.9 percentage points to overall comparable growth (https://investors.target.com/static-files/4b62d3d9-0ab649ee-80bd-cb04b419ccfb). In 2020 Q2, comparable sales grew $10.9 \%$ YoY, with digital comparable sales growing $195 \%$, contributing 13.4 percentage points to the overall number (https://investors.target.com/static-files/371fa aa7-ce10-40e1-a1e1-c07c95f3edfb). Levi Strauss \& Co pointed to the importance of the ability to shift to digital channels in its earnings release for the quarter ending 


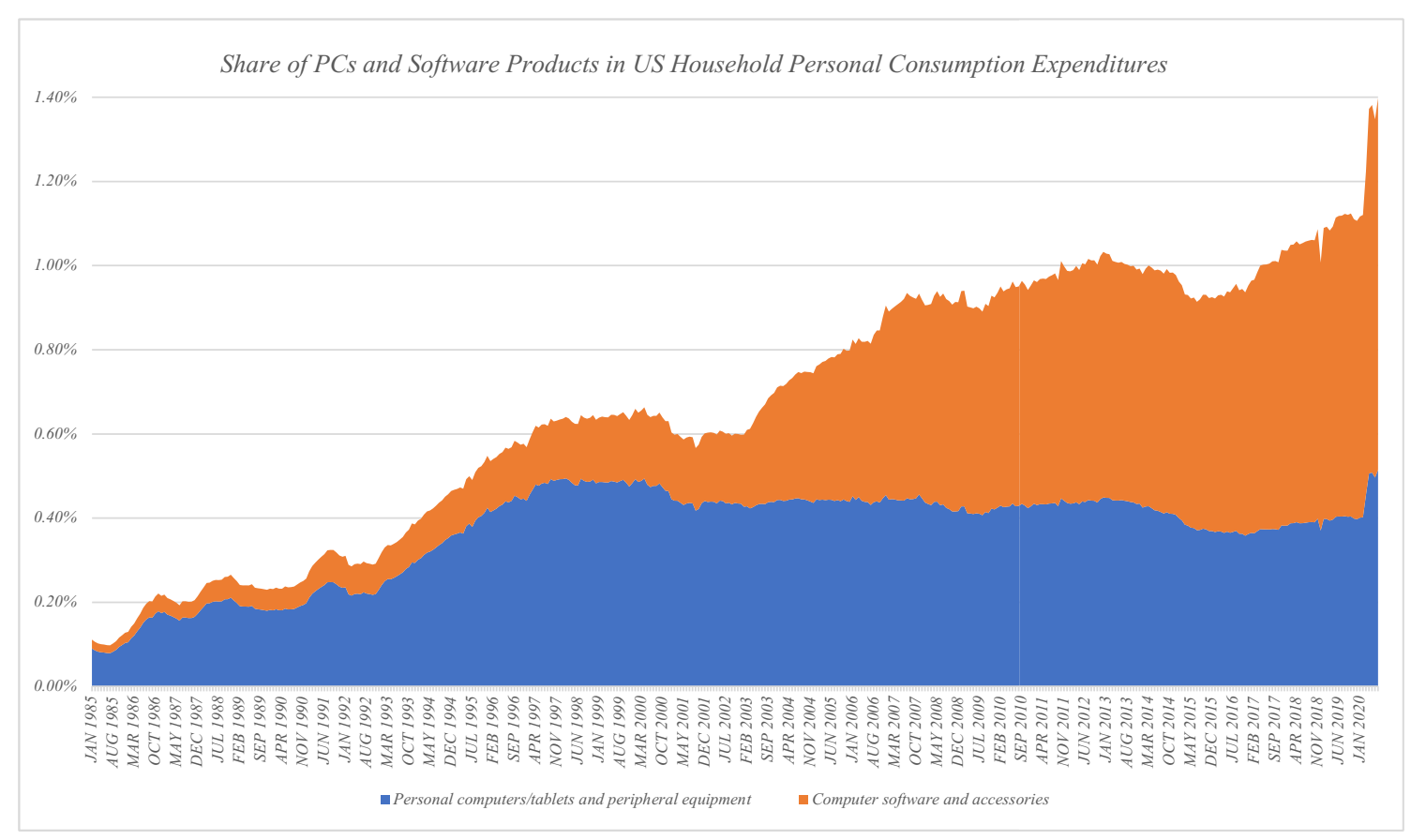

Sourse: U.S. Bureau of Economic Analysis

Note: Calculations exclude expenditures of nonprofit institutions serving households (NPISHs) from total household personal consumption expenditures.

Fig. 6 PCs/tablets and peripheral equipment and software in U.S. consumer spending. Source: U.S. Bureau of Economic Analysis. Note Calculations exclude expenditures of nonprofit institutions serving households (NPISHs) from total household personal consumption expenditures

May 24, 2020, their second quarter for 2020. Chip Bergh, Levi Strauss president and chief executive officer, stated, "the pandemic is accelerating retail landscape shifts and consumer behavior in ways that play to the strength of the Levi's brand. And we are doubling down on our digital transformation, incorporating the power of AI and data science and leveraging our iconic brands to have an even stronger focus on Gen $\mathrm{Z}$ and sustainability. We believe this will enable us to further grow our market leadership position and emerge from this crisis a stronger company" (https://s23.q4cdn.com/172692177/files/doc_financials /2020/q2/Exhibit-99.1-2Q-2020-Press-Release-FINAL .pdf). Whereas net revenues for the company fell $62 \%$ YoY, e-commerce grew $25 \%$. The share of e-commerce in total net revenues grew from $5 \%$ in the second quarter of the previous year to $15 \%$ in this most recent quarter.

The results for both firms illustrate the shift to digital commerce that boosted performance during the pandemic and that was enabled by technology tools and products.

More broadly, the shift in the composition of the S\&P 500 index shows the increasing relevance of the technology sector brought about during the pandemic. The share in the IT sector grew by nearly $24 \%$ between the end of 2019 and the end of August 2020. In contrast, the share in energy fell by $47 \%$ and in financials by $26 \%$ (https://www.spglo bal.com/spdji/en/idsenhancedfactsheet/file.pdf?calcFreque ncy $=$ M\&force_download $=$ true $\&$ hostIdentifier $=48190 \mathrm{c} 8 \mathrm{c}-$ 42c4-46af-8d1a-0cd5db894797\&indexId=340).

\subsection{Technology to address pandemic implications}

In addition to technology products and services playing a larger role in more traditional ways, they also contributed to understanding and getting through the pandemic, in new and unique ways.

For example, mobility data have taken on higher prominence in at least two ways. First, economists have increasingly used data on mobility to understand the effect of the pandemic on the economy. As one example, the Dallas Fed Mobility and Engagement Index combines several measures of mobility taken from mobile devices and constructs an index available at the MSA, county and state level (https ://www.dallasfed.org/research/mei.aspxL. The mobility trends appear to track with changes in policy, as well as with COVID-19-case trends.

Second, mobility data have become a tool available for tracing and contacting those potentially exposed to COVID19 cases. For example, Google and Apple announced the creation of a joint effort to create an "Exposure Notification" system that would continue to preserve privacy (https://covid 19.apple.com/contacttracing). As another example, South Korea uses mobility data, along with transaction data and 
camera footage to enable the collection of data for tracing and limiting the spread of the coronavirus (Fendos 2020).

Within the medical arena specifically, the COVID-19 High Performance Computing Consortium partners the federal government, academia and industry to provide high-performance computing to support COVID-19-related research. Industry members include IBM, Amazon Web Services, AMD, BP, D. E. Shaw Research, Dell Technologies, Google Cloud, Hewlett Packard Enterprise, Microsoft, NVIDIA and Intel (https://covid19-hpc-consortium.org/). The XPRIZE Pandemic Alliance shares ideas and resources related to COVID-19, with a key piece being data sharing and analysis via ML and AI. Technology-company partners include IBM, Intel and Nvidia (https://covid19.xprize.org/ fight-covid19\#overview).

\subsection{Summary}

To conclude, the technology sector has taken on a larger role in the wake of the pandemic, from occupying a larger share of the consumer wallet to enabling more traditional brick-and-mortar firms to maintain business to contributing more directly to understanding the effects of and confronting the pandemic.

\section{Prevalence of inequalities in access to and the use of technology}

This acceleration in digital transformation brings to light the inequities both within and across countries and highlights the critical importance of the digital divide. To put it succinctly, not everyone has been able to participate equally in the changes enabled by technology during the pandemicchanges that may exacerbate the already-existing digital divide.

\subsection{Learning from Home}

The movement to learning from home has highlighted very starkly the impact of digital inequities. Within the U.S., the Household Pulse survey provides a wealth of information, coupling information on changes to educational models with demographic data, such as income. As mentioned above, nearly all households with children of school age reported a change in the modality of education in Wave 1 data, collected between April 23 and May 5, with very similar rates across income groups (Table 1). ${ }^{10}$ Overall, about $72 \%$ of

\footnotetext{
10 https://www2.census.gov/programs-surveys/demo/technicaldocumentation/hhp/household-pulse-survey-questionnaire-week 1 -5.pdf, accessed September 2, 2020. The question referred to here is: "How has the coronavirus pandemic affected how the children in this
}

households with children reported a shift to online education. About 22\% reported a move to paper for remote learning. Within the modality data, households with incomes above \$150,000 reported moving to online education to a greater degree than households with incomes below $\$ 35,000,85 \%$ versus $59 \% .^{11}$

One relevant question in the survey relates to the availability of a computer within the household for educational use. ${ }^{12}$ Table 7 splits the possible responses into one group where the computer is always or usually available and another where a computer is sometimes, rarely, or never available. The data show that there are stark differences across income levels. Whereas $97 \%$ of households with incomes $\$ 150,000$ and above always or usually have a computer available, only $77 \%$ of households with incomes below $\$ 35,000$ do. Similarly, in Table 8 , the $98 \%$ of households with incomes \$150,000 and above with internet available for education always or usually available contrasts with the $83 \%$ of households with incomes below $\$ 35,000$.

As additional evidence, Pew conducted a survey in early April and found that only about $13 \%$ of Americans at that time considered the internet not very or not at all important during the pandemic, ranging from $8 \%$ for upperincome households to $15 \%$ for lower-income ones (https:// www.pewresearch.org/internet/wp-content/uploads/sites /9/2020/04/PI_2020.04.30_COVID-internet_REPORT.pdf). However, among those lower-income households with students whose schools were closed, many expressed concerns about the digital divide facing their children in doing schoolwork. Of those, $43 \%$ thought that it was very or somewhat likely that the child would have to do schoolwork by smartphone, $40 \%$ that public Wi-Fi would be needed due to unreliable internet at home and $36 \%$ that schoolwork could not be completed due to no access to a computer at home. The fractions for upper-income households were 10\%, $6 \%$ and $4 \%$, respectively.

\section{Footnote 10 (continued)}

household received education? Select all that apply." With selected choice, "There was no change because schools did not close."

11 https://www2.census.gov/programs-surveys/demo/technicaldocumentation/hhp/household-pulse-survey-questionnaire-week1 -5.pdf, accessed September 2, 2020. The question referred to here is: "How has the coronavirus pandemic affected how the children in this household received education? Select all that apply." With selected choices, "Pandemic impact on education-Classes normally taught in person moved to a distance-learning format using online resources, either self-paced or in real time" and "Classes normally taught in person moved to a distance-learning format using paper materials sent home to children."

12 The question referred to here is: "How often is a computer or other digital device available to children for educational purposes? Select only one answer." 
Table 7 Access to a computer for education

\begin{tabular}{|c|c|c|c|c|}
\hline \multicolumn{5}{|c|}{ US Census Bureau Household Pulse Survey (Wave 1) } \\
\hline \multicolumn{5}{|c|}{ All results for households with children enrolled in private or public school: } \\
\hline \multirow[t]{2}{*}{ Proportions responding } & \multicolumn{3}{|c|}{ Household income groups } & \multirow[t]{2}{*}{ Total } \\
\hline & $\begin{array}{l}\leq \$ 34,999 \text { House- } \\
\text { hold Income }\end{array}$ & $\begin{array}{l}\text { Household income between } \\
\$ 35,000 \text { and } \$ 149,000\end{array}$ & $\begin{array}{l}\geq \$ 150,000 \\
\text { household income }\end{array}$ & \\
\hline \multicolumn{5}{|c|}{ Computer available for education } \\
\hline Sometimes/rarely/never & 0.23 & 0.10 & 0.03 & 0.12 \\
\hline Always/usually & 0.77 & 0.90 & 0.97 & 0.88 \\
\hline \multicolumn{5}{|c|}{$\begin{array}{l}\text { Of those for whom computer always, usually, sometimes, or rarely available } \\
\text { Computer provided by family }\end{array}$} \\
\hline Yes & 0.60 & 0.73 & 0.84 & 0.71 \\
\hline No & 0.40 & 0.27 & 0.16 & 0.29 \\
\hline \multicolumn{5}{|c|}{ Computer provided by school } \\
\hline Yes & 0.45 & 0.39 & 0.30 & 0.39 \\
\hline No & 0.55 & 0.61 & 0.70 & 0.61 \\
\hline
\end{tabular}

The Household Pulse Survey data provide eight income groupings, which have been collected into the groups above. The $\$ 34,999$ and below group constitutes about $27 \%$ of the sample of families with children enrolled in public or private school, the $\$ 35,000$ to $\$ 149,999$ group about $58 \%$, and the $\$ 150,000$ and above group about $15 \%$

\begin{tabular}{|c|c|c|c|c|}
\hline \multicolumn{5}{|c|}{ US Census Bureau Household Pulse Survey (Wave 1) } \\
\hline \multicolumn{5}{|c|}{ All results for households with children enrolled in private or public school: } \\
\hline & \multicolumn{3}{|c|}{ Household income groups } & \multirow[t]{2}{*}{ Total } \\
\hline & $\begin{array}{l}\leq \$ 34,999 \\
\text { household income }\end{array}$ & $\begin{array}{l}\text { Household income between } \\
\$ 35,000 \text { and } \$ 149,000\end{array}$ & $\begin{array}{l}\geq \$ 150,000 \\
\text { household income }\end{array}$ & \\
\hline \multicolumn{5}{|c|}{ Internet available for education } \\
\hline Sometimes/rarely/never & 0.17 & 0.07 & 0.02 & 0.09 \\
\hline Always/usually & 0.83 & 0.93 & 0.98 & 0.91 \\
\hline \multicolumn{5}{|c|}{$\begin{array}{l}\text { Of those for whom internet always, usually, sometimes, or rarely available } \\
\text { Internet provided by family }\end{array}$} \\
\hline Yes & 0.93 & 0.98 & 0.99 & 0.97 \\
\hline No & 0.07 & 0.02 & 0.01 & 0.03 \\
\hline \multicolumn{5}{|c|}{ Internet provided by school } \\
\hline Yes & 0.04 & 0.01 & 0.00 & 0.02 \\
\hline No & 0.96 & 0.99 & 1.00 & 0.98 \\
\hline
\end{tabular}

The Household Pulse Survey data provide eight income groupings, which have been collected into the groups above. The $\$ 34,999$ and below group constitutes about $27 \%$ of the sample of families with children enrolled in public or private school, the $\$ 35,000$ to $\$ 149,999$ group about $58 \%$, and the $\$ 150,000$ and above group about $15 \%$
Comparisons across countries provide even starker differences. ${ }^{13}$ In some countries, such as Denmark, Slovenia,

\footnotetext{
13 The World Bank provides a range of information on remote learning and Ed Tech at https://www.worldbank.org/en/topic/edutech/brief /edtech-covid-19. There is a discussion on China's response at https:// en.unesco.org/news/how-china-ensuring-learning-when-classes-aredisrupted-coronavirus. Also see Basto-Aguirre et al. (2020).
}

Norway and Poland, almost all students have a computer at home that they can use for schoolwork. In Indonesia, though, only $34 \%$ do. Other countries with less than $50 \%$ of students having access include the Philippines and Morocco (OECD 2020).

Access to the internet is also important for remote learning. The percent of students with access to the internet at home ranges from near-universal in countries such as Denmark and 
Finland to less than $60 \%$ in countries such as Indonesia, the Philippines and Peru (OECD 2020).

On both measures, access to a computer and access to the internet, there is a range within countries as well, depending on the socio-economic status of the students. For example, access to a computer for schoolwork ranges from 7\% to $94 \%$ within Peru and 22\% to 93\% in Brazil (Marinelli et al. 2020). In addition, teachers do not always have the skills to incorporate digital devices in teaching (Basto-Aguirre et al. 2020).

\subsection{Work from home and other activities}

As discussed above, certain jobs are not even feasibly done remotely, and the prevalence of the ability to do so varied across income groups both pre- and mid-pandemic. In prepandemic evidence, whereas in the lowest quartile of workers in the U.S., only $9 \%$ of workers could potentially work from home, in the highest quartile, $61 \%$ could (Table 3 ). The March 2020 poll mentioned earlier also shows disparities across income groups (Table 5). As for cross-country evidence, both Dingel and Neiman (2020) and Brussevich et al. (2020) found a positive relationship between country-level per capita income and the ability to work from home.

In addition to the nature of work, access to technology is also important for working from home, as well as doing other activities remotely. Evidence suggests a wide degree of disparity across groups within countries and across countries. International Telecommunication Union (ITU) data for 201819 (https://www.itu.int/en/ITU-D/Statistics/Pages/stat/defau lt.aspx) show that the percent of households with a PC ranges widely across countries. While some countries, such as Germany and the U.S., have rates around $90 \%$, other countries have much lower rates. Mobile phone access rates are generally much higher, but, depending on the task, the PC may often be a better tool than a phone. Access to the internet also varies widely, with UN data (https://unstats.un.org/sdgs/indicators/ database// showing the number of people per 100 inhabitants who use the internet ranging from 5 to 100 in 2018 (Table 9).

\subsection{Summary}

Such disparities in access to technology mean that the shift toward remote learning, working and performing other activities has impacted different groups very differently, with some much more likely to be left behind, often those who would potentially have the most to gain from access to digital tools.

\section{Conclusion}

The coronavirus pandemic has changed the ways people interact and economies function by impelling populations to reduce their direct, in-person interactions with others, a
Table 9 Internet access Source: https://unstats.un.org/sdgs/indicators/ database/, accessed August 26, 2020

Internet users per 100 people

\begin{tabular}{|c|c|}
\hline Geographic area & Value (2018) \\
\hline World & 51 \\
\hline Algeria & 49 \\
\hline Azerbaijan & 80 \\
\hline Southern Asia & 33 \\
\hline Austria & 87 \\
\hline Bahrain & 99 \\
\hline Belgium & 89 \\
\hline Central and Southern Asia & 34 \\
\hline Bolivia (Plurinational State of) & 44 \\
\hline Bosnia and Herzegovina & 70 \\
\hline Brazil & 70 \\
\hline Bulgaria & 65 \\
\hline Belarus & 79 \\
\hline Cambodia & 40 \\
\hline Europe & 82 \\
\hline Colombia & 64 \\
\hline Costa Rica & 74 \\
\hline Croatia & 75 \\
\hline Cyprus & 84 \\
\hline Czechia & 81 \\
\hline Denmark & 97 \\
\hline Dominican Republic & 75 \\
\hline Estonia & 89 \\
\hline Finland & 89 \\
\hline France & 82 \\
\hline Georgia & 63 \\
\hline State of Palestine & 64 \\
\hline Germany & 90 \\
\hline Greece & 73 \\
\hline Haiti & 32 \\
\hline China, Hong Kong Special Administrative Region & 91 \\
\hline Hungary & 76 \\
\hline Iceland & 99 \\
\hline Indonesia & 40 \\
\hline Iran (Islamic Republic of) & 70 \\
\hline Iraq & 75 \\
\hline Ireland & 85 \\
\hline Israel & 84 \\
\hline Italy & 74 \\
\hline Côte d'Ivoire & 47 \\
\hline Japan & 91 \\
\hline Kazakhstan & 79 \\
\hline Republic of Korea & 96 \\
\hline Kuwait & 100 \\
\hline Latvia & 84 \\
\hline Lithuania & 80 \\
\hline Luxembourg & 97 \\
\hline China, Macao Special Administrative Region & 84 \\
\hline
\end{tabular}


Table 9 (continued)

\begin{tabular}{|c|c|}
\hline \multicolumn{2}{|l|}{ Internet users per 100 people } \\
\hline Geographic area & Value (2018) \\
\hline Malaysia & 81 \\
\hline Malta & 82 \\
\hline Mauritius & 59 \\
\hline Mexico & 66 \\
\hline Mongolia & 47 \\
\hline Montenegro & 72 \\
\hline Morocco & 65 \\
\hline Netherlands & 95 \\
\hline Niger & 5 \\
\hline Norway & 96 \\
\hline Paraguay & 65 \\
\hline Peru & 53 \\
\hline Poland & 78 \\
\hline Portugal & 75 \\
\hline Qatar & 100 \\
\hline Romania & 71 \\
\hline Russian Federation & 81 \\
\hline Saint Vincent and the Grenadines & 22 \\
\hline Saudi Arabia & 93 \\
\hline Serbia & 73 \\
\hline Singapore & 88 \\
\hline Slovakia & 81 \\
\hline Viet Nam & 70 \\
\hline Slovenia & 80 \\
\hline Spain & 86 \\
\hline Sweden & 92 \\
\hline Thailand & 57 \\
\hline United Arab Emirates & 98 \\
\hline Tunisia & 64 \\
\hline Turkey & 71 \\
\hline Ukraine & 63 \\
\hline North Macedonia & 79 \\
\hline Egypt & 47 \\
\hline United Kingdom of Great Britain and Northern Ireland & 95 \\
\hline Uruguay & 75 \\
\hline Uzbekistan & 55 \\
\hline Zambia & 14 \\
\hline
\end{tabular}

shift that has been facilitated by the IT sector. Indeed, we've seen how the pandemic has accelerated digital transformation, increased the importance of technology in the economy and society, and highlighted the need to address inequalities in access to and the use of technology. The longevity of the changes wrought by the pandemic remains unclear at this point. However, given that the digital transformation process was already underway, at least some of the impacts are likely to stay. Most importantly, the pandemic has brought to light the need to ensure that access to the tools and resources needed in this new more digital age are made available to the widest set of people possible.

\section{References}

Augenstein, Jared. 2020. Opportunities to expand Telehealth use amid the coronavirus pandemic. https://www.healthaffairs.org/ do/10.1377/hblog20200315.319008/full/. Accessed 2 Sept 2020.

Basto-Aguirre, Nathalie, Paula Cerutti, and Sebastián Nieto-Parra. 2020. COVID-19 can widen educational gaps in Latin America: Some lessons for urgent policy action. Vox. https://vox.lacea .org/?q=blog/covid19_widen_educational_gaps\#ref. Accessed 3 Sept 2020.

Bosworth, Arielle, Joel Ruhter, Lok Wong Samson, Steven Sheingold, Caroline Taplin, Wafa Tarazi, and Rachael Zuckerman, 2020. Medicare beneficiary use of telehealth visits: Early data from the start of COVID-19 pandemic. U.S. Department of Health and Human Services. https://aspe.hhs.gov/system/files/pdf/263866/ HP_IssueBrief_MedicareTelehealth_final7.29.20.pdf.

Brussevich, Mariya, Era Dabla-Norris, and Salma Khalid. 2020. Who will bear the brunt of lockdown policies? Evidence from teleworkability measures across countries. https://www.imf.org/ / media/Files/Publications/WP/2020/English/wpiea2020088-print -pdf.ashx. Accessed 2 Sept 2020.

Brynjolfsson, Erik, John J. Horton, Adam Ozimek, Daniel Rock, Garima Sharma, and Hong-Yi TuYe. 2020. COVID-19 and remote work: An early look at US data. National Bureau of Economic Research Working Paper 27344. https://www.nber.org/papers/ w27344.pdf. Accessed 2 Sept 2020.

Dingel, Jonathan I., and Brent Neiman. 2020. How many jobs can be done at home? https://bfi.uchicago.edu/wp-content/uploads/ BFI_White-Paper_Dingel_Neiman_3.2020.pdf. Accessed 2 Sept 2020. https://github.com/jdingel/DingelNeiman-workathome/ blob/master/country_correlates/output/country_workathome.csv. Accessed 2 Sept 2020.

Education Week. 2020. Map: Coronavirus and school closures. https ://www.edweek.org/ew/section/multimedia/map-coronavirus-andschool-closures.html. Accessed 2 Sept 2020.

Engebretson, Joan. 2020. Report: Work-day home wi-fi usage doubles with COVID-19 but hits plateau, telecompetitor.com. https://www. telecompetitor.com/report-work-day-home-wi-fi-usage-doubleswith-covid-19-but-hits-plateau/. Accessed 2 Sept 2020.

Fendos, Justin. 2020. How surveillance technology powered South Korea's COVID-19 response. https://www.brookings.edu/techs tream/how-surveillance-technology-powered-south-koreas-covid -19-response/. Accessed 3 Sept 2020.

Hamel, Liz, Lunna Lopes, Cailey Muñana, Jennifer Kates, Josh, Michaud, and Mollyann Brodie, Mollyann. 2020. KFF coronavirus poll: March 2020. https://www.kff.org/global-health-policy/ poll-finding/kff-coronavirus-poll-march-2020/. Accessed 2 Sept 2020.

Marinelli, Horacio Alvarez, Elena Aria Ortiz, Andrea Bergamaschi, Angela Lopez, Sanchez, Alessandra Noli, Marclea Ortiz Guerrero, Marcela Perez Alfaro, Sabine Riebele-Auborg, Maria Camila Rivera, Rudolfo Scannone, Madiery Vasquez, and Adriana VIteri. 2020. La educacion en tiempos del coronavirus: Los sistemas educativos de America Latina y el Caribe ante COVID-19. https ://publications.iadb.org/publications/spanish/document/La-educa cion-en-tiempos-del-coronavirus-Los-sistemas-educativos-deAmerica-Latina-y-el-Caribe-ante-COVID-19.pdf. Accessed 3 Sept 2020.

OECD. 2020. Learning remotely when schools close: How well are students and schools prepared? Insights from PISA. https://www. 
oecd.org/coronavirus/policy-responses/learning-remotely-whenschools-close-how-well-are-students-and-schools-prepared-insig hts-from-pisa-3bfda1f7/. Accessed 3 Sept 2020.

Rae, Matthew, Cynthia Cox, and Gary Claxton. 2020. Coverage and utilization of telemedicine services by enrollees in large employer plans. https://www.healthsystemtracker.org/brief/coverage-andutilization-of-telemedicine-services-by-enrollees-in-large-emplo yer-plans/. Accessed 2 Sept 2020.

United Nations. 2020. COVID-19 impact on education. https://en.unesc o.org/covid19/educationresponse/. Accessed 2 Sept 2020.

UNESCO. 2020. National education responses to COVID-19: Summary report of UNESCO'S online survey, April 2020.

Weigel, Gabriela, Amrutha Ramaswamy Laurie Sobel, Alina Salganicoff, and Juliette Cubansk, 2020. Opportunities and barriers for telemedicine in the U.S. during the COVID-19 emergency and beyond. https://www.kff.org/womens-health-policy/issue-brief /opportunities-and-barriers-for-telemedicine-in-the-u-s-durin g-the-covid-19-emergency-and-beyond/. Accessed 2 Sept 2020.

Publisher's Note Springer Nature remains neutral with regard to jurisdictional claims in published maps and institutional affiliations.

Carolyn Evans is Chief Economist at Intel Corporation. Prior to joining Intel, Carolyn held the positions of Associate Professor of Economics at Santa Clara University, Senior Economist at the Board of Governors of the Federal Reserve, Senior Staff Economist for International Trade on the President's Council of Economic Advisers, and Economist at the Federal Reserve Bank of New York. Carolyn holds a Ph.D. and M.A. in Economics and an A.B. in East Asian Languages and Civilizations, all from Harvard University. She also holds a M.Sc. from the London School of Economics. 